\title{
APLIKASI BERBASIS WEB PENYELESAIAN MASALAH PROGRAM LINIER STANDAR MAKSIMAL DENGAN KELUARAN SESUAI PRODUK KEMASAN TERKECIL
}

\author{
Putut Sri Wasito \\ Program Studi Teknik Informatika \\ Fakultas sain dan Matematika Universitas Diponegoro
}

\begin{abstract}
Secara umum masalah pemrograman linear diselesaikan dengan metode simpleks dengan sejumlah output riil dalam desimal atau pecahan Format campuran. Penyelesaian tidak bersifat operasional karena produsen tidak selalu mampu membuat kemasan produk terkecil sesuai dengan unit pada penyelesaian, menjadi operasional, hasil penyelesaian ini dapat dibulatkan sesuai dengan paket terkecil yang dipilih. Masalah terbatas manufaktur yang memiliki sistem aplikasi program linier dapat diatasi dengan menyediakan sistem yang mirip dengan aplikasi berbasis web. Penelitian ini menyusun sebuah sistem aplikasi berbasis web untuk memecahkan program linear standar yang menghasilkan pendapatan maksimum yang menggunakan perangkat lunak maksimum PHP, data yang dimasukkan melalui formulir dan kemudian diambil dengan metode POST, kemudian mendirikan sebuah matriks, dilakukan dengan iterasi antara baris dalam operasi matriks yang memenuhi kriteria optimal. Dengan memilih kemasan terkecil yang digunakan 0,25 unit atau 0,50 unit, sistem memeriksa jumlah produk yang memiliki pembulatan terkecil sesuai dengan paket yang dipilih, maka sistem mempersiapkan dan menyajikan laporan persediaan dan pendapatan.
\end{abstract}

Kata Kunci: metode simpleks, paket terkecil, berbesis web

\section{Pendahuluan}

Pemrograman linier berkenaan dengan masalah memaksimalkan atau meminimalkan fungsi sasaran yang berbentuk linier yang kendala-kendalanya harus berbentuk linier, jadi kendalanya merupakan persamaan atau ketaksamaan linier. Topik ini lebih tepat disebut optimalisasi linier. Masalah optimalisasi linier muncul secara alamiah dan sangat elementer dalam banyak aplikasi terutama dalam masalah perencanaan ekonomi. Perorangan atau koperasi selaku produsen yang memproduksi lebih dari satu produk selalu memiliki masalah untuk menentukan jumlah masing-masing produk, serta kemasan terkecil yang digunakan sehingga menghasilkan pendapatan maksimal tetapi masih memenuhi persediaan sarana yang ada.

Prosedur penyelesaian untuk dua perubah atau maksimal tiga perubah biasa digunakan metode grafis sedang untuk sebarang jumlah perubah digunakan suatu prosedur penyelesaian yang sangat efisien yang dinamakan metode simplex.

Metode simplex adalah suatu algoritma yang merupakan suatu proses di mana suatu prosedur sistematis diulang-ulang sampai yang diinginkan tercapai (solusi optimal). Setiap kali mengulang prosedur sistematis yang bersangkutan dinamakan suatu iterasi.

Metode simplex merupakan prosedur aljabar, yaitu menggunakan iterasi untuk menaikkan atau menurunkan nilai fungsi pendapatan [6].

Metode simplex menghasilkan penyelesaian optimal dengan keluaran nilai perubahperubahnya merupakan bilangan riil, baik berbentuk pecahan campuran maupun desimal. Keluaran ini jika dikaitkan dengan kemasan terkecil suatu produk menjadi tidak operasional, semisal dihasilkan penyelesaian dengan metode Simplex, nilai $\mathrm{x} 1=3 \frac{4}{7}$, produsen sangat sulit untuk membuat kemasan terkecil seberat atau sebesar $\frac{1}{7}$ satuan, demikian juga jika dihasilkan $\mathrm{x} 1=4,456, \quad$ tidak semua produsen dapat membuat kemasan terkecil seberat atau sebesar 0,001 satuan. Kasus memaksimalkan pendapatan dengan persediaan sarana yang terbatas disebut kasus program linier standar maksimal.

Walaupun tersedia sistem aplikasi yang dapat menyelesaikan masalah program linier tetapi tidak dikaitkan dengan kemasan terkecil dan tidak semua produsen memiliki sistem aplikasi tersebut. 
Hal tersebut yang mendasari pentingnya penelitian penyelesaian masalah program linier standar maksimal berbasis web sehingga mudah diakses oleh produsen dan keluarannya dapat disesuaikan dengan kemasan terkecil yaitu 0,25 atau 0,50 satuan sehingga lebih operasional.

Dari latar belakang tersebut muncul masalah bagaimana menyusun sistem aplikasi berbasis web yang dapat menyele- saikan masalah program linier standar maksimal tetapi dengan keluaran yang dapat disesuaikan dengan kemasan terkecil yang ada yaitu 0,25 dan 0,50 satuan..

\section{Tinjauan Pustaka}

Tesis ini disusun melalui tinjauan pustaka antara lain publikasi di Computer Journal, 8 berjudul "A tree Search Algorithm for Mixed Integer Programming Problem" mengemukakan bahwa masalah program linier dapat diarahkan menjadi program integer yaitu menggunakan $A$ tree search algorithm [5] sedang dalam penelitian ini keluarannya bukan integer.

Jurnal yang berjudul "A Shadow Price in Integer Programming for Management Decision" yang dimuat dalam European Journal of Operational Research, 37 mengemukakan bahwa keluaran dapat diarahkan ke bentuk tertentu dengan mengubah nilai-nilai pada harga jual yang berarti mengubah koefisien fungsi sasaran [10], pada penelitian ini nilai koefisien fungsi sasaran tidak diubah.

Jurnal yang berjudul"On alternative mixed integer programming formulations and LP-based heuristics for lot-sizing with setup times" yang dimuat dalam Journal of theOperational Research Society,Doi : 10.1057/ palgrave.jors.2601996 mengemukakan bahwa masalah program linier dapat di formulasikan ke bentuk program integer campuran melakukan pendekatan heuristics dengan melakukan berkali-kali percobaan sehingga diperoleh model penyelesaian (Denizel dan Sural, 2005), dalam penelitian penyelesaian masalah langsung dapat diperoleh tanpa melalui pembentukan model.

Jurnal yang berjudul "New Integer programming formulation and an algorithm for ordered cutting stock pro-blem" yang dimuat dalam Journal of the Operational Research Society, nomor 19 mengemukakan bahwa keluaran dapat diarahkan ke bentuk tertentu dengan menggunakan "cutting stock problem" yaitu "memotong" daerah fisibel yang berarti memengubah satu atau beberapa fungsi kendala, berarti juga mengubah persediaan yang ada (Alves dan Valerino, 2009), dalam penelitian ini fungsi kendala tidak berubah.

\section{Sistem Informasi}

Sistem adalah sekumpulan komponen yang saling berhubungan yang bekerja sama menuju pencapaian tujuan bersama dengan menerima masukan dan menghasilkan keluaran dalam proses transformasi yang teratur. Umpan balik adalah data mengenai kinerja sistem. Pengendalian adalah komponen yang mengawasi umpan balik serta membuat penyesusaian apapun yang dibutuhkan oleh komponen masukan dan pemrosesan yang memastikan bahwa keluarannya benar [9].

Sistem informasi adalah suatu cara tertentu untuk menyediakan informasi yang dibutuhkan oleh organisasi untuk beroperasi dengan cara yang sukses dan untuk organisasi bisnis dengan cara yang menguntungkan [12].

Pada dasarnya sistem informasi merupakan suatu sistem yang dibuat oleh manusia yang terdiri dari komponen-komponen dalam organisasi untuk mencapai suatu tujuan yaitu menyajikan informasi. Sistem informasi dalam suatu organisasi yang mempertemukan kebutuhan pengolahan transaksi, mendukung operasi, bersifat manajerial dan kegiatan strategi dari suatu organisasi dan menyediakan pihak luar tertentu laporan-laporan yang diperlukan.

Pengembangan sistem informasi merupakan proses atau prosedur yang harus diikuti untuk melaksanakan seluruh langkah dalam menganalisis, merancang, mengimplementasikan, dan memelihara sistem informasi. Proses-proses pengembangan ini dikenal dengan daur hidup pengembangan sistem atau SDLC (System Development Life Cycle). SDLC yang terkenal biasa disebut dengan model waterfal,

Analisis Kebutuhan adalah kegiatan mengumpulkan kebutuhan secara lengkap kemudian kemudian dianalisis dan didefinisikan kebutuhan yang harus dipenuhi oleh program yang akan dibangun. Fase ini harus dikerjakan 
secara lengkap untuk bisa menghasilkan desain yang lengkap. Desain Sistem adalah kegiatan yang dikerjakan dikerjakan setelah kebutuhan selesai dikum -

pulkan secara lengkap. Implementasi dan Pengujian Unit adalah penterjemahan ke dalam kode-kode sesuai dengan bahasa pemrogran yang sudah ditentukan.

Pengujian Sistem adalah kegiatan menyatukan unit-unit program, selanjutnya dilakukan pengujian secara menyeluruh.

Perawatan Sistem adalah kegiatan melakukan pemeliharaan termasuk penyesuaian atau perubahan karena adaptasi dengan situasi sebenarnya.

\section{Sistem Aplikasi}

Sistem aplikasi adalah kombinasi dari sistem informasi dan aktivitas orang yang menggunakan sistem itu untuk mendukung operasi dan manajemen atau berarti merupakan program yang digunakan oleh pengguna untuk menyelesaikan suatu tugas tertentu [1].

Perancangan sistem aplikasi menggunakan 4 desain yaitu : Desain Sistem, Desain Masukan, Desain Keluaran dan Desain Antar Muka.

\section{Desain Sistem}

Desain Sistem didefinisikan sebagai penggambaran, perencanaan, dan pembuatan sketsa atau pengaturan beberapa elemen yang terpisah ke dalam satu kesatuan yang utuh dan berfungsi. Pada bagian ini permasalahan yang ada dipecah menjadi beberapa masalah dalam bentuk modul-modul sehingga menjadi cukup mudah untuk ditangani.

\section{Desain Masukan}

Dalam sebuah sistem aplikasi, pemrosessan data masukan dapat dilakukan dalam waktu yang berbeda-beda. Data bisa saja diproses langsung oleh sistem, ada pula data yang tidak langsung diproses. Berdasarkan waktu pemrosesan data tersebut, jenis pemrosesan dibedakan menjadi batch processing dan online processing.

Disebut batch processing apabila data yang dimasukkan tidak diproses langsung, tetapi dikumpulkan dulu dalam satu batch (kumpulan), baru kemudian akan diproses. Jenis pemrosesan data seperti ini dilakukan dengan mengumpulkan data-data dalam dokumen-dokumen, misalnya data-data transaksi disimpan dalam dokumen transaksi, data-data penjualan disimpan dalam dokumen penjualan, kemudian data tersebut dikumpulkan dalam batch-batch, dan dilakukan validitasi. Setelah itu data dipindahkan ke dalam media yang dapat dibaca oleh komputer.

Sedangkan yang disebut online processing adalah jika data yang dimasukkan langsung diproses oleh sistem, dalam hal ini data dimasukkan langsung ke dalam komputer dengan menggunakan beberapa perangkat masukan seperti keyboard, mouse, scanner dan lain sebagainya.

\section{Desain Keluaran}

Suatu sistem aplikasi harus menyediakan keluaran yang sesuai dengan yang dikehendaki oleh pemakai. Pada bagian ini pemakai menentukan format keluaran yang diharapkan. Keluaran yang dihasilkan oleh sistem aplikasi terbagi menjadi dua yaitu keluaran internal dan keluaran eksternal.

Keluaran internal adalah keluaran yang langsung digunakan oleh pemakai, biasanya berupa laporan-laporan yang berhubungan dengan manajemen di dalam organisasi, misalnya laporan pendapatan, laporan persediaan, laporan perbandingan dan lain-lain.

Keluaran eksternal merupakan keluaran yang ditujukan kepada pihak luar organisasi, seperti brosur, kartu garansi, dan lain sebagainya.

Dalam melakukan desain keluaran perlu diperhatikan identifikasi keluaran agar sesuai dengan kebutuhan pemakai, membuat spesifikasi kebutuhan keluaran dan melakukan validasi terhadap keluaran.

\section{Desain Antar Muka}

Dalam merancang sebuah antar muka bagi pemakai, perlu diperhatikan kemampuan dari pemakai tersebut, baik kemampuan fisik maupun kemampuan mental. Hal ini sangat penting, mengingat kemampuan pemakai sangat beragam. Pemakai tentunya menginginkan satu antar muka yang sederhana dan interaktif serta menggunakan istilah-istilah yang mudah dimengerti oleh pemakai.

Perancangan antar muka menggunakan pendekatan eksploratori merupakan pendekatan 
yang paling efektif terhadap perancangan antar muka. Pendekatan ini menggunakan protitipe dengan membuat tiruan antar muka di atas kertas, kemudian dilakukan evaluasi dengan pemakai sebelum mengembangkannya pada layar yang mensimulasikan interaksi dengan pemakai.

\section{Metode Simplex}

Dalam buku yang berjudul "Linear Programming and Extension", menyatakan bahwa untuk menyelesaikan persoalan program linier dengan metode simplex untuk kasus memaksimumkan dan meminimumkan caranya berbeda. Model matematika dari permasalahan program linier dapat dinyatakan dalam bentuk linier sebagai :

Menentukan $X=\left[x_{i}\right], i=1,2,3, \ldots ., n$

Yang memenuhi kendala : $A_{m \times n} X_{n \times 1}(\leq,=, \geq)$ $\mathrm{B}_{\mathrm{mx} 1}$

Mengoptimalkan Fungsi Tujuan $\mathrm{Z}_{1 \times 1}=\mathrm{C}_{1 \times n} \mathrm{X}_{\mathrm{nx} 1}$. [6]

Berikut ini langkah-langkah penyelesaian persoalan program linier dengan tujuan memaksimumkan nilai fungsi pendapatan sesuai dengan metode simplex :

1. Mengubah semua kendala ke Bentuk Kanonik (yang semula menggunakan tanda pertidaksamaan menjadi persamaan) dengan menambah perubah (variabel) Slack s. Perubah-perubah slack yang ada imasukkan (ditambahkan) ke fungsi sasaran dan diberi koefisien 0, Langkah 1 menyebabkan matriks A menjadi berukuran $\mathrm{m} \times(\mathrm{n}+\mathrm{m})$ dan memuat matriks identitas berordo m., kemudian lanjutkan menyusun tabel awal simplex.

2. Menentukan kolom kunci yaitu menentukan perubah yang masuk menjadi perubah basis yang baru. Kolom $\mathrm{j}$ adalah kolom kunci $\leftrightarrow$ $\left(\mathbf{Z}_{\mathbf{j}}-\mathbf{C}_{\mathbf{j}}\right)>\mathbf{0}$ terkecil

3. Menentukan baris kunci yaitu menentukan perubah basis lama yang harus keluar digantikan oleh perubah basis yang baru.

Baris I adalah baris kunci $\leftrightarrow$ Index $_{i}>0$ terkecil

4. $a_{\mathrm{ij}}$ disebut elemen kunci, lakukan operasi baris : baris I baru $=$ baris I lama $: a_{i j}$
5. Lakukan operasi baris pada baris yang lain sehingga elemen-elemen yang sekolom dengan elmen kunci menjadi 0

6. Tabel optimal $\leftrightarrow$ untuk semua $\mathrm{j}$ nilai $\left(\mathbf{Z}_{\mathbf{j}}-\mathbf{C}_{\mathbf{j}}\right)$ $>0$

7. Jika tabel belum optimal kembali elangkah 2

Teorema-teorema simplex

Kesahihan algoritma simplex dijamin oleh 3 teorema utama simplex yaitu :

Teorema 1:

Jika ada Penyelesaian Fisibel (PF) maka penyelesaian tersebut adalah Penyelesaian Fisibel Basis (PFB).

Teorema 2 :

Suatu $\mathrm{X}$ anggota $\mathrm{PFB} \leftrightarrow \mathrm{X}$ titik ekstrem dari PF. Teorema 3 :

Jika terdapat nilai optimal maka nilai optimal tersebut terletak pada titik ekstrem.

\section{Permutasi}

Permutasi adalah penyusunan kembali suatu kumpulan objek dalam urutan yang berbeda dari urutan yang semula. Sebagai contoh, Jika terdapat suatu untai abjad $a b c d$, maka untai itu dapat dituliskan kembali dengan urutan yang berbeda: $a c b d$, dacb, dan seterusnya. Selengkapnya ada 24 cara menuliskan keempat huruf tersebut dalam urutan yang berbeda satu sama lain.

Dalam penelitian ini permutasi digunakan untuk menentukan banyaknya kondisinyang diakibatkan oleh pembulatan.

Setiap pembulatan dilakukan 2 kali yaitu keatas dan kebawah, sehingga jika terdapat $\mathrm{k}$ buah nilai yang dibulatkan maka terdapat $2^{\mathrm{k}}$ kondisi.

\section{Web}

WWW ( World Wide Web) atau yang sering disebut sebagai "web" saja merupakan aplikasi internet yang paling populer. Demikian populernya hingga banyak orang yang keliru mengidentikkan web dengan internet. Secara teknis, web adalah sebuah sistem dimana informasi dalam bentuk teks, gambar, suara, dan lain-lain yang tersimpan dalam sebuah internet webserver dipresentasikan dalam bentuk hypertext. Informasi di web dalam bentuk teks umumnya ditulis dalam format HTML (Hypertext Markup Language) [8]. 
Sejak tahun 1997 untuk membuat suatu situs web dapt digunakan Dreamweaver yang dikembangkan oleh Macromedia Inc. Dalam tesis ini digunakan Macromedia Dreamweaver 8 digunakan untuk membuat form yang saling terkait dengan PHP dan MySQL. Bahasa program yang banyak dipakai para desainer website antara lain ASP, PHP, JSP, Java Scripts, Java applets, XML, Ajax dan sebagainya yang merupakan bahasa pendukung yang bertindak sebagai pengatur dinamis, dan interaktifnya situs. (Hypertext Markup Language) [8].

Sejak tahun 1997 untuk membuat suatu situs web dapt digunakan Dreamweaver yang dikembangkan oleh Macromedia Inc. Dalam tesis ini digunakan Macromedia Dreamweaver 8 digunakan untuk membuat form yang saling terkait dengan PHP dan MySQL. Bahasa program yang banyak dipakai para desainer website antara lain ASP, PHP, JSP, Java Scripts, Java applets, XML, Ajax dan sebagainya yang merupakan bahasa pendukung yang bertindak sebagai pengatur dinamis, dan interaktifnya situs.

\section{Metodologi}

Penelitian ini menggunakan langkahlangkah :

\section{Menyusun diagram alir program.}

Dengan memperhatikan permasalahan dan kerangka teori maka disusun diagram alir sesuai gambar 1.

Sesuai diagram alir program maka banyaknya kendala $(\mathrm{m})$ dan banyaknya perubah (n) maksimal 2 digit, nilai-nilai $\mathrm{a}_{\mathrm{ij}}, \mathrm{b}_{\mathrm{i}}, \mathrm{C}_{\mathrm{j}}$ harus berupa numerik.

\subsection{Memilih perangkat lunak}

Penelitian ini bertujuan untuk menyusun sistem aplikasi yang berbasis web sehingga dipilih perangkat lunak PHP yang memiliki kelebihan antara lain :

1. Bahasa pemrograman PHP adalah sebuah bahasa script yang tidak melakukan sebuah kompilasi dalam penggunaanya.

2. Web Server yang mendukung PHP dapat ditemukan dimana - mana dari mulai apache, IIS, Lighttpd, hingga Xitami dengan konfigurasi yang relatif mudah.
3. Dalam sisi pengembangan lebih mudah, karena banyak nya milis - milis dan developer yang siap membantu dalam pengembangan.

4. Dalam sisi pemahamanan, PHP adalah bahasa scripting yang paling mudah karena memiliki referensi yang banyak.

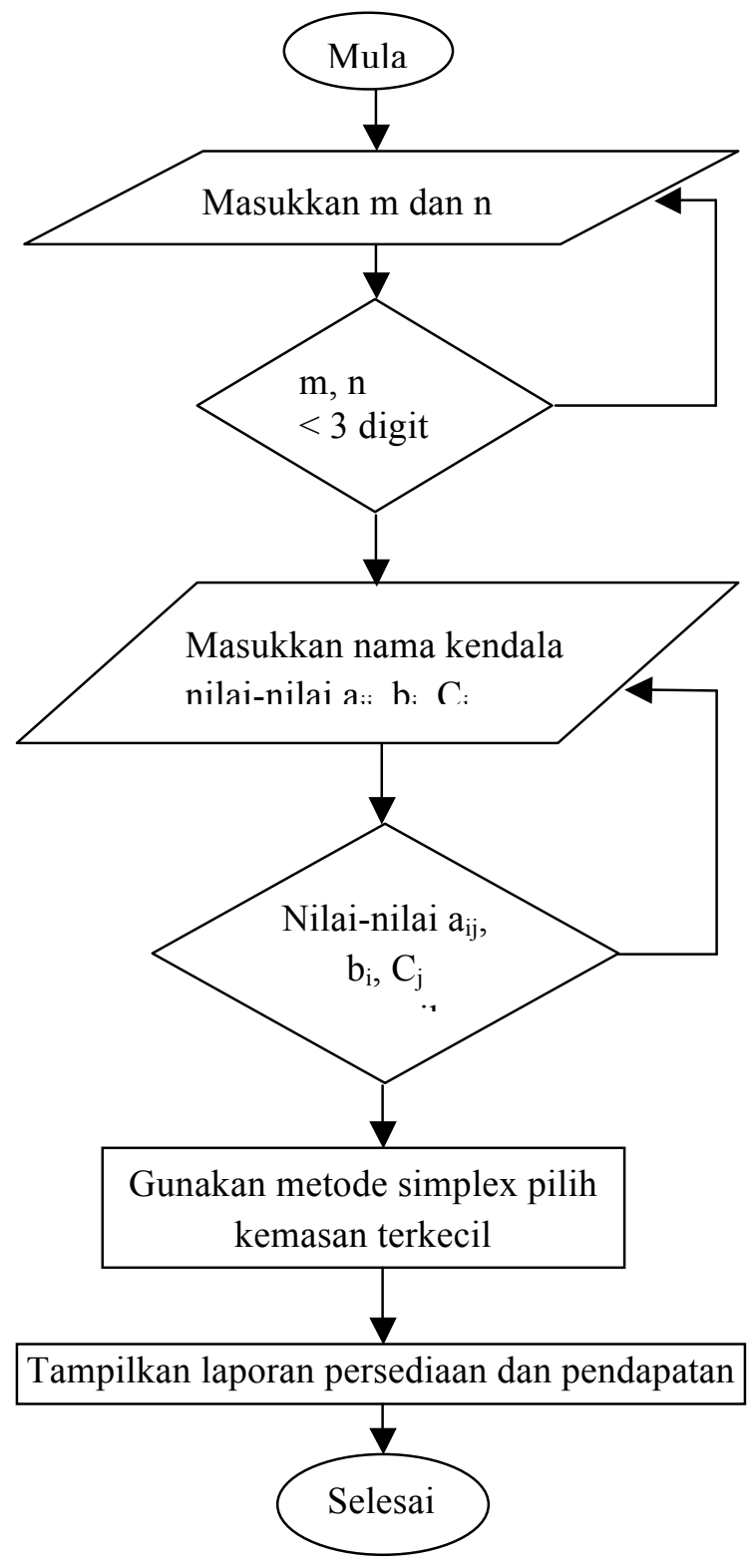

Gambar 1. Diagram alir program

5. PHP adalah bahasa open source yang dapat digunakan di berbagai mesin (Linux, Unix, Macintosh, Windows) dan dapat dijalankan secara runtime melalui console serta juga dapat menjalankan perintah-perintah system. 
6. PHP memiliki fasilitas perubah \$ POST untuk mengambil, menyimpan data dari form serta memprosesnya.

Pada penelitian ini data dimasukkan lewt form selanjut nya disimpan dan diproses di dalam perubah \$_POST. Pada saat tombol kendali pada form ditekan, data akan dikirim ke server dan diproses oleh PHP. PHP akan menyimpan data yang diterima ke dalam perubah \$_POST memprosesnya sesuai dengan deskripsi yang ada.

Deskripsi pada PHP disunting menggunakan perangkat lunak Dreameaver 8 tombol Code untuk menyunting dan memeriksa deskripsi dan tombol Design untuk menampilkan hasil deskripsi.

\section{Merencanakan tampilan antar muka}

Sistem aplikasi direncakan memiliki 6 tampilan antar muka yang saling terhubung dan secara fungsional saling berurutan meliputi :

\section{Rencana Tampilan Step1}

Tampilan Stepl menampilkan iterasi simplex langkah per langkah sehingga dipenuhi kriteria maksimal yaitu bila untuk semua $\mathrm{j}$ nilai $Z_{j}-C_{j} \geq 0$, dilengkapi dengan tombol KEMBALI untuk kembali ke tampilan Input 1 serta tombol pilihan pembulatan 0,25 dan 0,50 untuk melanjutkan program masuk Step 2 seperti ditunjukkan pada gambar 2 .

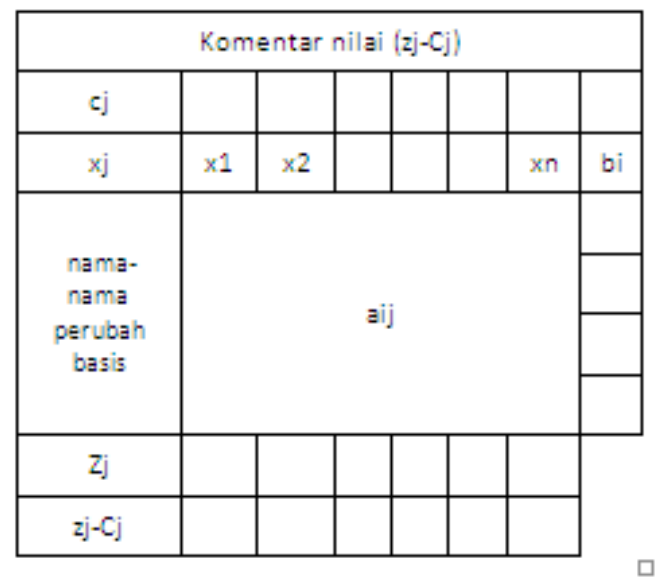

Gambar 2. Rencana Tampilan Step1

\section{Rencana Tampilan Step2}

Tampilan Step2 menampilkan laporan persediaan dan pendapatan untuk semua kondisi sesuai pembulatan yang dipilih dilengkapi dengan tombol KEMBALI untuk kembali ke tampilan Stepl untuk memeriksa hasil ierasi simplex serta dapat memilih angka pembulatan yang lain seperti ditunjukkan pada gambar 3 .

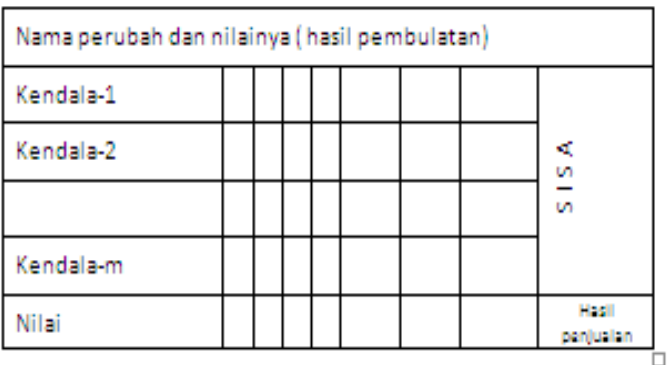

Gambar 3. Rencana Tampilan Step2

\section{Hasil dan pngujian}

\subsection{Hasil Penelitian}

Hasil dari penelitian ini adalah program aplikasi berba-

sis web yang dapat digunakan untuk menyelesaikan masalah program linier standar maksimal dengan keluaran yang dapat disesuaikan dengan kemasan terkecil yang disajikan dalam bentuk hasil antar muka. Untuk lebih jelasnya dapat dilihat contoh kasus sebagai berikut :

Sebuah industri rumah tangga memproduksi 3 macam kue kering yaitu kue A, $\mathrm{B}$ dan C. Untuk memproduksi kue kering seberat $1 \mathrm{Kg}$, tersebut dibutuhkan bahan gula, tepung dan coklat serta persediaan yang ada dalam satuan kantung sesuai matriks seperti pada tabel 1.

Tabel 1 Kebutuhan, persediaan dan pendapatan

\begin{tabular}{|l|c|c|c|c|}
\hline & A & B & C & Persediaan \\
\hline Gula & 2 & 3 & 4 & 100 \\
\hline Tepung & 7 & 3 & 3 & 120 \\
\hline Coklat & 2 & 1 & 4 & 40 \\
\hline Pendapatan & 3.000 & 3.500 & 2.750 & \\
\hline
\end{tabular}

\section{Hasil tampilan step1}

Melalui Tampilan Step 1, pengguna dapat melihat hasil iterasi Simplex sampai di peroleh nilai optimal. Dimulai dengan menampilkan 
tahap ke-1 yaitu menampilkan tabel awal simplex sesuai gambar 4 .

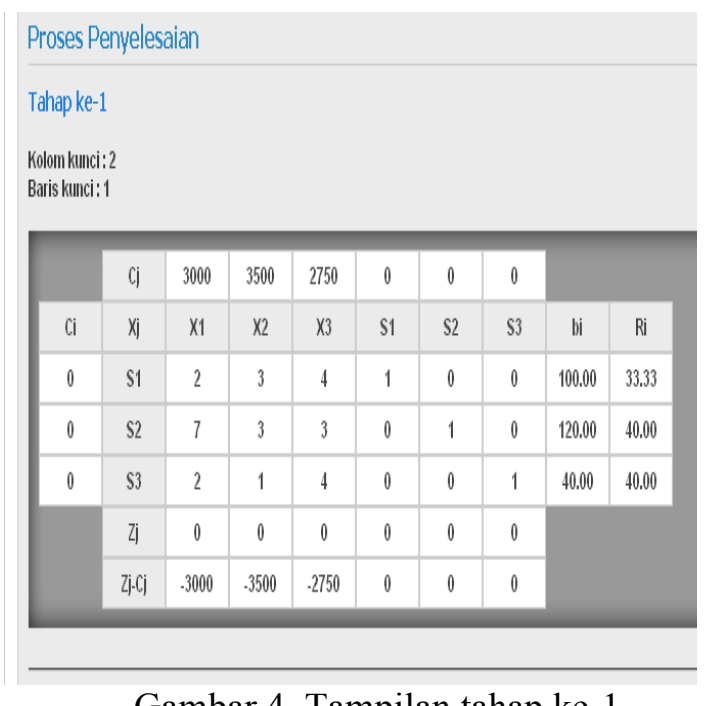

Gambar 4. Tampilan tahap ke-1

Kolom ke-2 dipilih sebagai kolom kunci karena nilai $(\mathrm{Zj}-\mathrm{Cj})$ pada kolom ke-2 merupakan nilai negatip terkecil untuk semua $\mathrm{j}$. Baris ke-1 dipilih sebagai baris kunci karena nilai Ri pada baris ke-1 merupakan nilai positip terkecil untuk semua i. Proses dilanjutkan tahap ke-2 yaitu mengganti basis $\mathrm{S} 1$ dengan $\mathrm{X} 2$ sehingga diperoleh hasil sesuai gambar 5 .

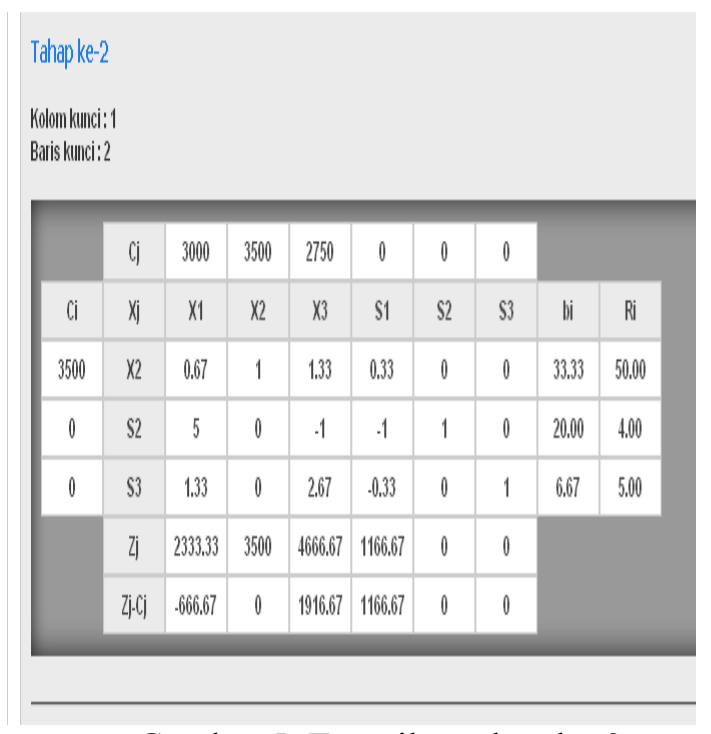

Gambar 5. Tampilan tahap ke-2

Selanjutnya kolom ke-1 dipilih sebagai kolom kunci karena nilai $(\mathrm{Zj}-\mathrm{Cj})$ pada kolom ke1 merupakan nilai negatip terkecil untuk semua $j$.
Baris ke-2 dipilih sebagai baris kunci karena nilai $\mathrm{Ri}$ pada baris ke- merupakan nilai positip terkecil untuk semua i.

Proses dilanjutkan tahap ke-3 yaitu mengganti basis S2 dengan X1 sehingga diperoleh hasil sesuai gambar 6 .

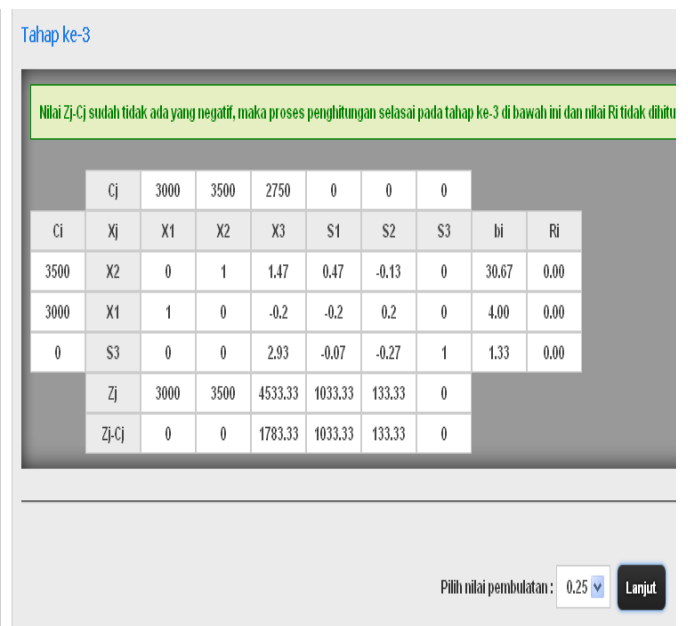

Gambar 6. Tampilan tahap ke-3

Pada tahap ke-3, semua nilai $(\mathrm{Zj}-\mathrm{Cj}) \geq 0$ untuk semua $\mathrm{j}$, berarti telah diperoleh tabel optimal, proses dihentikan.

Nilai pembuat optimal adalah $\times 2=30,67$ dan $\mathrm{X} 1=4,00, \mathrm{X} 3$ tidak muncul sebagai basis berarti nilai $\mathrm{X} 3=0$.

Terdapat tombol Kembali untuk kembali ke tampilan informasi dan tombol pilihan pembulatan 0,25 dan 0,50 serta tombol Lanjut untuk melanjutkan ke laporan persediaan dan pendapatan.

\section{Hasil tampilan laporan persediaan dan pendapatan.}

Laporan persediaan dan pendapatan dihasilkan dari Step2, setelah sistem menerima angka pembulatan yang dipilih pengguna maka akan diperiksa besarnya nilai-nilai perubah basis, yaitu dibagi dengan angka pembulatan yang dipilih, jika nilai perubah basis kelipatan dari angka pembulatan yang dipilih maka nilai tersebut tidak dibulatkan, sebaliknya jika nilai perubah basis bukan kelipatan dari angka pembulatan yang dipilih maka nilai perubah basis tersebut dibulatkan keatas dan kebawah, selanjutnya di hitung sisa atau kekurangan 
kendala dan pendapatan atau keuntungan. Sesuai contoh kasus, untuk pembulatan 0,50 dapat dilihat pada gambar 4.8 yang menampilkan matriks persediaan tanpa pembulatan dilanjutkan dengan gambar 7 yang menampilkan Laporan persediaan dan pendapatan dengan pembulatan 0,50 .

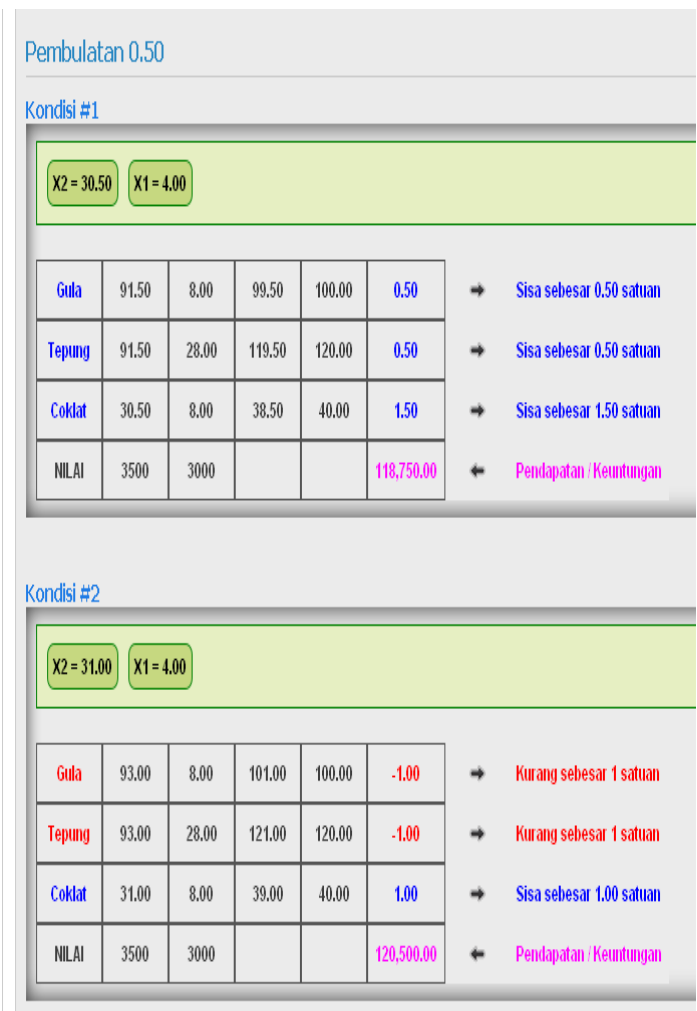

Gambar 7. Tampilan hasil pembulatan 0,50

Dari gambar 7 terlihat bahwa jika digunakan kemasan terkecil $0,50 \mathrm{~kg}$ yang berarti di lakukan pembulaan 0,50 maka terdapat 2 kondisi.

Kondisi 1 : Diproduksi kue B $=30,50 \mathrm{~kg}$ dan $\mathrm{A}=4,00 \mathrm{~kg}$,

Pendapatan $=$ Rp. 118.750,00, sedang persediaan :

Gula sisa 0,50 kantung

Tepung sisa 0,50 kantung

Coklat sisa 1,50 kantung

Kondisi 2 : Diproduksi kue B $=31,00 \mathrm{~kg}$ dan kue $\mathrm{A}=4,00 \mathrm{~kg}$.

Pendapatan Laba $=$ Rp. 120.500,00,

sedang

persediaan :

Gula kurang 1 kantung
Tepung kurang 1 kantung

Coklat sisa 1,00 kantung,

Tampilan Laporan Persediaan dengan pembulatan 0,25 dapat dilihat pada gambar 8 .

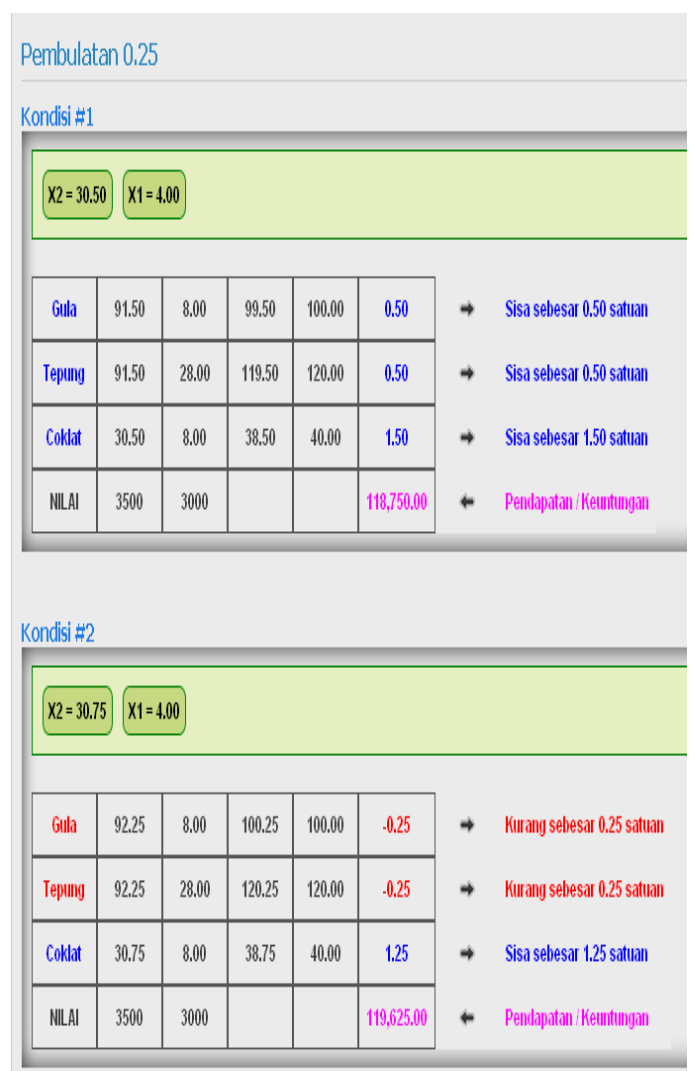

Gambar 8. Tampilan hasil pembulatan 0,25

Dari gambar 8 terlihat bahwa jika digunakan kemasan terkecil $0,25 \mathrm{~kg}$ yang berarti di lakukan pembulaan 0,25 maka terdapat 2 kondisi.

Kondisi 1 : Diproduksi kue B $=30,50 \mathrm{~kg}$ dan kue $\mathrm{A}=4,00 \mathrm{~kg}$, dengan

Pendapatan $=$ Rp. $118.750,00$, sedang

Persediaan :

Gula sisa 0,50 kantung

Tepung sisa 0,50 kantung

Coklat sisa 1,50 kantung

Kondisi 2 : Diproduksi kue B $=30,75 \mathrm{~kg}$ dan kue $\mathrm{A}=4,00 \mathrm{~kg}$, dengan

Pendapatan $=$ Rp. 119.625,00,

sedang

persediaan :

Gula kurang 0,25 kantung

Tepung kurang 0,25 kantung

Coklat sisa 1,25 kantung. 


\subsection{Pengujian Hasil Penelitian}

Hasil pengujian menggunakan sistem black box sesuai tabel 2 .

Tabel 2 Tabel hasil pengujian

\begin{tabular}{|c|c|c|c|}
\hline No. & Pengujian & Hasil & Catatan \\
\hline 1. & $\begin{array}{l}\text { Menu } \\
\text { utama }\end{array}$ & berhasil & $\begin{array}{l}\text { Tombol } \\
\text { LANJUT } \\
\text { aktif }\end{array}$ \\
\hline 2. & $\begin{array}{l}\text { Menu } \\
\text { informasi }\end{array}$ & berhasil & $\begin{array}{l}\text { Tombol } \\
\text { LANJUT } \\
\text { aktif }\end{array}$ \\
\hline 3. & Input1 & berhasil & $\begin{array}{l}\mathrm{m}, \mathrm{n} \\
\text { maksimal } 2 \\
\text { digit, tombol } \\
\text { LANJUT } \\
\text { aktif }\end{array}$ \\
\hline 4. & Input 2 & berhasil & $\begin{array}{l}\text { Semua } \\
\text { masukan } \\
\text { berupa } \\
\text { numerik, } \\
\text { tombol } \\
\text { LANJUT } \\
\text { aktif }\end{array}$ \\
\hline 5. & Step 1 & berhasil & $\begin{array}{l}\text { Dapat } \\
\text { menampilkan } \\
\text { iterasi } \\
\text { simplex } \\
\text { sehingg } \\
\text { dicapai } \\
\text { kriteria } \\
\text { maksimum, } \\
\text { tombol } \\
\text { pilihan - }\end{array}$ \\
\hline 6. & & & $\begin{array}{l}\text { Pembulatan } \\
\text { aktif. }\end{array}$ \\
\hline 6. & Step2 & berhasil & $\begin{array}{l}\text { Dapat } \\
\text { menampilkan } \\
\text { laporan } \\
\text { persediaan } \\
\text { dan } \\
\text { pendapatan } \\
\text { sesuai nilai } \\
\text { pembulatan } \\
\text { yang dipilih, } \\
\text { tobol } \\
\text { KEMBALI } \\
\text { aktif } \\
\end{array}$ \\
\hline
\end{tabular}

Dilakukan pengujian menggunakan sistem black box yaitu pengujian yang didasarkan pada pengecekan terhadap detil perencanaan, menggunakan struktur kontrol dari desain program secara prosedural untuk membagi pengujian kedalam beberapa kasus pengujian.

Pada Input1 banyaknya kendala (m) dan banyaknya perubah (n) terbatas 2 digit.

Pada Input2 masukan nama kendala maksimum 20 karakter, nilai-nilai $a_{i j}$, $b_{i}$ dan $C_{j}$ adalah numerik maksimal digit, penyajian desimal menggunakan notasi titik (. ) semisal 4.25 dan bukan 4,25.

Pada Step1 ditampilkan iterasi sesuai metode Simplex sampai diperoleh tabel optimal disertai tombol pilihan pembulatan 0,25 dan 0,50 serta tombol kembali ke Input1.

Pada Step2 ditampilkan form Laporan Persediaan dan Pendapatan sesuai pembulatan yang dipilih, persedeiaan yang sisa diberi warna biru sedang persediaan yang kurang diberi warna merah. Pendapatan diletakkan pada sudut kanan bawah dengan warna magenta. Step-2 dilengkapi dengan tombol kembali untuk kembali ke tampilan dari Step-1 sehingga dapat kembali melihat hasil dari ierasi Simplex

\section{Kesimpulan}

Berdasarkan hasil penelitian dan pengujian, disimpulkan bahwa dapat disusun program aplikasi berbasis web menggunakan perangkat lunak PHP yang dapat menyelesaikan masalah program linier standar maksimal dengan banyak perubah lebih besar sama dengan dua. Data dimasukkan lewat form, diambil dengan metode POST, disusun dalam bentuk matriks dan dioperasikan antar baris sehingga memenuhi kriteria optimal, setelah dipilih angka pembulatan, sistem akan menghitung dan menampilkan laporan persediaan dan pendapatan dalam bentuk form. Spesifikasi dari sistem adalah :

a. Terbatas pada kasus standar maksimal

b. Banyaknya kendala dan perubah maksimal 2 digit.

c. Nama kendala maksimum 20 karakter.

d. Nilai-nilai $a_{i j}$, $b_{i}$ dan $C_{j}$ adalah numerik maksimal 6 digit.

e. Mampu menampilkan nilai persediaan dan pendapatan sampai dengan 6 digit. 


\section{Daftar Pustaka}

[1] Agus Mulyanto, 2009. Sistem Informasi Konsep \& Aplikasi. Pustaka Pelajar, Yogyakarta

[2] Alves, C dan Valerino, J M., 2009. New integer programming formulation and an exact algorithm for ordered cutting stock problem. Journal of the Operational Research Society, 19

[3] Ariyoso, 2009. Liniear peogramming. Websitehttp://ariyoso.wordpress.com/2009 /11/20/aplikasi-liniear-programming/ diakses 14 April 2011

[4] Christos H.Papadimitriou, 1988. Combinatorial Optimization Algorithms And Complexity. University of California_berkely, New York

[5] Dakin, R.J. ,1965. A tree Search Algorithm for Mixed Integer Programming Problem. Computer Journal, 8

[6] Danzjg, G.B., 1963. Linear Programming and Extension. Princenton University Press, Princenton, N.Y

[7] Denizel, M dan Sural, H., 2005. On alternative mixed integer programming formulations and LP-based heuristics for lotsizing with setup times.Journal of the Operational Research Society, doi:10.1057/palgrave.jors. 2601996.
[8] Dodit Supriyanto, 2008. Buku Pintar Pemrograman PHP. OASE Media, Bandung.

[9] James A. O'Brien, 2008. Introduction to Information Systems, 12th Edition. Alih Bahasa, Salemba Empat, Jakarta

[10] Kim, S., and Cho, S. A, 1988. Shadow Price in Integer Programming for Management Decision. European Journal of Operational Research, 37

[11] Mcleod, Raymond, 2006. Management Information System A Study Of ComputerBased Information System. Prentice Hall.

[12] Satzinger, Jackson, Burd, 2004. Systems Analysis and Design in a Changing World, 3rd ed, Boston, Mass.: Thompson Learning, Inc. 